\title{
A Pair of Desert Saints: Name Symbolism in Peter Shaffer's Equus
}

\section{Hassell Simpson}

The names of the two protagonists in Peter Shaffer's drama Equus allude to "desert saints" in different senses, suggesting the celibacy, loneliness, and idealism of those characters, as well as their conflict and kinship on matters of rebellion and religious belief. Other names in the play, including that of the hospital setting, refer to a variety of cultural antecedents. Although the effects of these names are much subtler than those of such names in fiction, the end result for Shaffer is a verbal symbolism that amplifies and undergirds his potent thesis.

British Playwright Peter Shaffer's stunning drama Equus drew rave notices at its New York opening in 1974 for its superb theatricality - its skillful interweaving of a troubled boy's actions and emotions both past and present; its daring evocation of horses by actors garbed in chestnut velvet, elevated on "hooves," and masked in openwork "horseheads" of metal and leather; its then-startling nude scene; and above all (though less obviously) its devastating critique of modern psychiatry, on the one hand as quite capable of destroying passion and faith, but on the other as powerless to replace them in the hearts and minds of patients.

The very success of the play's dramatic devices and theme has served, however, to obscure the more subtle but nonetheless poetic arrangement of significant nomenclature that undergirds

Names 41.3 (September 1993):183-193

ISSN:0027-7738

(c) 1993 by The American Name Society 


\section{Names 41.3 (September 1993)}

Shaffer's bold message and innovative techniques. The names the playwright chose for his major characters and even for the hospital where the present action occurs, all subtly allude to a wide variety of cultural antecedents: two stories out of the Old Testament and another by Sir Walter Scott, medieval European monasticism, a striking nude by Diego Velásquez, a nursery rhyme, and the religious cultists and outlaw horsemen of the American West. Not only that, but the names of the two chief characters remarkably allude to "desert saints" in two different senses, deriving from different cultures, countries, and periods. Thus the parallels and contrasts between these two "desert saints" named Martin Dysart and Alan Strang will illuminate the central conflict between them and at the same time reinforce their growing kinship. These two given names and two surnames at least, if not others as well, were evidently chosen by Shaffer to make those connections, if only for himself.

In Equus the leading character is a psychiatrist working mainly with children at a hospital in southern England. Martin Dysart, who explores and presumes to rearrange the emotions and repressions of others, is himself an emotion-starved, sexually repressed man who dreams of Greece as a land of sunlight, violence, and passion but who has not so much as kissed his wife in six years. In effect he has chosen a celibate state of contemplation and has withdrawn from the life of involvement to devote himself to an ideal existing chiefly in books and in his mind (scene 25). In doing so he resembles the religious hermits of old, who betook themselves to desert places in order to serve God undistracted by temptations of the flesh; but whereas they sought to replace one kind of passion with another, Dysart only dreams of passion, faith, and ritual. One of those places of anchorite seclusion (called deserta in Latin) takes its name, Dysart, from a corruption of that word; it lies in the Scottish county of Fife (Chadwick 146; Hanks and Hodges Surnames 154; Black 235). Thus in giving his psychiatrist a Scottish-monastic surname, a Scottish wife, and a Scots accent in one speech, the playwright calls up a series of images that amplify and reinforce the loneliness, idealism, and celibacy of that character. That the allusions might have been unconscious and inadvertent does not invalidate my claim here. The fact of un- 
consciousness might only indicate the depth and zeal with which Shaffer experienced the lives of his characters. And that many readers of his script, and most members of his theater audiences, would probably miss these allusions is no argument against them, either; readers and critics are constantly reassessing works of art and finding previously unsuspected (and sometimes nonexistent) meanings in them.

The reference to monkish celibacy in Dysart's surname ${ }^{1}$ is extended in his Christian name of Martin, which alludes to Saint Martin of Tours, the father of monasticism in Gaul. The best-known legend about Saint Martin says that as a pagan soldier he once gave half his cloak to warm a naked beggar (Hanks and Hodges First Names 227); and Shaffer probably reflects that legend in his scene 35 , in which, having led young Alan Strang to relive an incident of stripping off his clothing, the modern pagan Martin Dysart covers the naked, frantic boy with a blanket and tries to calm him. Love and charity are no doubt motives for Dysart as for his putative patron saint, though Christian belief certainly is not a factor for the psychiatrist. Dysart is spiritually dry, his marriage a barren, loveless desert. His soul, unsaintlike, can see and envy but cannot experience the passion and faith of a boy.

Alan Strang's surname suggests, variously, his strange behavior before, during, and after his violent blinding of several horses; his estrangement first from his family and then from society; the strand or beach where as a child he experienced his revelation of horse-as-divinity; and his being stranded in the desert (desertum, Dysart) of Rokeby Psychiatric Hospital during the action of the play. The name Strang also suggests strangle, in Alan's long silences and his self-constricted speech (with a side glance at strangles or strangullion, a disease of horses characterized by inflammation and swelling of the throat glands). Pronounced with [a] in the European style, as in Old English strang 'strong,' the name also suggests the strength of Alan's convictions and the power of his creative imagination, which fuses Judeo-Christian myths with pagan and animal elements to form a personal religion. Most interestingly, the common noun Strang in German and Yiddish means halter, ${ }^{2}$ a head-harness or restraint for horses and other large animals, a sense that would have obvious 


\section{Names 41.3 (September 1993)}

pertinence to Alan Strang, who not only led horses by their halters or bridles but who also in his religious ecstasy put a chain into his own mouth as a bit and beat his thigh with a coat hanger used as a whip. And Alan's first name suggests "alien" and "alienation," which would aptly describe him and his position in society. ${ }^{3}$

The passionate but deluded faith of Alan, and the contrast between his parents Frank and Dora Strang's attitudes on sex and religion, may indicate that Shaffer had some knowledge of James Jesse (or Jesse James) Strang, an American Mormon leader and former skeptic who in 1844 claimed the succession to the murdered Joseph Smith as head of the Church of Jesus Christ of Latter-Day Saints. Strang based his claim on a vision he said God had sent to proclaim him prophet, but his claim was rejected and he was expelled from the church. Undaunted, he formed a new cult, advocating and practicing polygyny until he was shot and killed in 1856 (Britannica IX: 599-600; Columbia 2051). ${ }^{4}$ The fusion of sex, rebellion, violence, and religious innovation in the life and death of J. J. Strang has some striking parallels as well as contrasts with the unhappy marriage of Frank and Dora Strang, in their disagreement about religion, and with the emotional disturbance of their seventeen-year-old son Alan, who worships horses yet blinds six of them when they seem to be disapproving his first sexual encounter. (Sex equi $=$ six horses in Latin.) Since the renegade Mormon J. J. Strang may have been called Jesse James, and since Shaffer's Young Horseman calls himself "Jesse James" in scene 10, it appears that the playwright drew not only the name Strang but also the motifs of religious enthusiasm and rebellion from the life of James Jesse Strang. And because in one sense J. J. Strang might be called a "desert saint," as in the titles of Anderson's and Quaife's books about him and the Mormons, one can see that the names Strang and Dysart may have been closely associated in Shaffer's mind, and that Alan Strang's name must have been chosen for its implications of latter-day sainthood in the American West.

Knowledge of J. J. Strang's career is quite arcane, considered against young Alan's knowledge (drawn from television and film) of American cowboys as stoic-heroic figures devoted to horses. No reader or theatergoer can miss those allusions, while 
apart from Mormon historians hardly anyone, even in America, knows about J. J. Strang today. Did Shaffer know? During the three years that he lived in New York he worked in a bookstore and in a public-library branch (Smith 452), so the sources of that knowledge were readily accessible to him.

Why would the playwright have chosen to name his two leading characters after "desert saints," anyway? Shaffer presents Dr. Dysart as a lonely man, spiritually dry and sexually unfulfilled, who nevertheless strives to do good; thus the psychiatrist is an authentic latter-day "saint" in the desert or Waste Land of the twentieth century - one who also sees himself in dreams as the high priest of some bloody sacrifice. Dysart, for his part, joins with his playwright-creator in seeing Alan Strang as at one time a happier, more fulfilled person than his therapist, Strang having been able and joyfully willing to abase himself before the gods of his own creation and to derive spiritual nourishment from that worship (distorted though the boy's faith became, through the intervention of fleshly temptation in the person of Jill Mason). ${ }^{5}$ Dysart and Alan are flawed saints, to be sure; but saints, being human, were never perfect except perhaps in their pursuit of perfection in faith. I suggest that the playwright's dual aim is to expose the modern rejection of religious for scientific faith as shallow and unsatisfying - and at the same time to expose personal, individual religions like Alan Strang's as distorted and false, though sometimes very satisfying. Thus Equus is Shaffer's Waste Land, showing the human predicament as essentially barren and hopeless, while leaving open the possibility of redemptive individual acts of charity and integrity, such as those rendering Dysart, Alan, and Hesther Salomon models, despite their errors, of "authenticity."

Hesther Salomon is the official who sends Alan Strang to Dysart and his hospital, as an alternative to a prison term. The surname of this magistrate appropriately alludes to the wisest judge of Biblical antiquity: Solomon, the man of peace and king of Israel whose shrewd offer to divide a disputed child between two women revealed the child's true mother (1 Kings 3 ). Since Alan Strang was in one sense a "disputed child" and because he was emotionally and metaphorically divided between his parents and 


\section{Names 41.3 (September 1993)}

was actually turned into such a son as neither had desired, it seems clear that Hesther Salomon has been carefully named and deliberately appointed by Shaffer to see Alan restored to wholeness through therapy rather than to maintain the division by sending him to prison.

The magistrate's first name, Hesther, alludes to another striking figure of the Old Testament: Esther, the beautiful Jewish girl who became the second queen of Ahasureus (Xerxes I), king of Persia. The Book of Esther tells how she saved the Jewish inhabitants of her husband's kingdom from extermination and enabled them to destroy their enemies. Hesther Salomon, this modern Esther, has arranged to save Alan, temporarily at least, and perhaps also to destroy his mental or emotional "enemies." Peter Shaffer, reared in an Orthodox Jewish home, would have known these stories of Solomon and Esther from his childhood.

"Rokeby Psychiatric Hospital," the setting for the present action in Equus, is said to be in southern England, evidently in Hampshire (scene 25), but I can find no significant "Rokeby" associated with that county. However, there may be a literary connection with Sir Walter Scott's long Romantic poem Rokeby, having to do with a knight and a castle of that name in Yorkshire following the Battle of Marston Moor. Indeed, Scott's Canto 3 includes a story about a man called "Allen-a-dale," pointedly neither a knight nor a noble. This bandit chieftain gets the girl he desires in spite of her parents' opposition - possibly an ironic reversal of Alan Strang's timorous, unsuccessful approach to Jill, and also possibly a parallel with the boy's professed inability to ride. That same canto also mentions "Dalton-hall" as a castle, and Shaffer may have taken the name of his stable-owner, Harry Dalton, from that source. Even the poet's nationality and his surname of Scott may resonate here, for Shaffer has carefully called attention to the Scottish attributes of Dr. Dysart. ${ }^{6}$

Some readers may find these possibilities tenuous, largely because of Scott's warmly Romantic-heroic presentation, which is quite different from the chilly deterministic vision of Shaffer's script. Alternatively, then, I would assert that, consciously or not, the playwright might also have taken the name Rokeby from The Rokeby Venus, one of several titles attaching to a memorable nude 
by the seventeenth-century Spanish court painter Diego Velásquez. ${ }^{7} \mathrm{~A}$ treasure of the National Gallery in London, the painting was once at Rokeby in Yorkshire, hence its name (Levey 89). It shows the back of a female nude reclining on her side; she looks into a mirror held by a Cupid, represented in customary fashion as a nude small boy with wings. Unlike the fleshy nudes of Rubens, this Venus has the more slender, graceful form regarded as ideal in our day. Although both the body and the composition are quite beautiful, Velásquez made no attempt to idealize his model - as Shaffer makes none to idealize Jill Mason. And while the picture is not notably sensuous, it forms a perfect parallel for Jill, who, by swiftly removing all her clothing, becomes a goddess of Love, challenging Alan Strang to remove his. Alan, in the raw, is certainly no Cupid - far from it; but for a moment on the stage, as continuously in Velásquez's painting, we can see two handsome nudes, one of them from the back. ${ }^{8}$ Shaffer's calling the psychiatric hospital "Rokeby" and his including a modern Venus if not also a Cupid, are no doubt ironic; for all of Dr. Dysart's skill in calling up an attractive nude out of Alan's past, he cannot give any of his disturbed patients a joyous appreciation of graceful young bodies. The most he can do is render those young persons "normal," which is to say unimpassioned. Lust they may retain or regain; love he cannot impart.

Yet The Rokeby Venus has her non-ironic applications in Equus as well. The goddess of Love clearly has claims to influence in a work about love and sex, though Jill is her only likely devotee in Shaffer's play. If Frank and Dora Strang and Dr. and Mrs. Dysart represent failures of love, and if Alan Strang represents its shocking (or perhaps inspiring) perversion, then Jill Mason represents the serene acceptance of youth, beauty, and sexuality - an acceptance that one can easily see in Velásquez's painting, with its splendid nude gazing into Cupid's mirror. Alan's rejection of Jill and her attitude is of course a sad consequence of his upbringing in a household riven by dissension between belief and atheism on the one hand and by Mr. Strang's secret sensuality on the other.

The proper names thus called up are dropped into Shaffer's script as if at random, so that as words they do not draw imme- 
diate attention to themselves. Indeed, the characters seem quite unconscious of their own names and, with one exception, the names of others; the single possible exception is unstressed, easily overlooked, and therefore debatable (scene 6, italics added):

DYSART: It's that lad of yours who started it off. Do you know it's his face I saw [in my dream] on every [sacrificial] victim across the stone?

HESTHER: Strang?

DYSART: He has the strangest stare I ever met.

Since the two syllables italicized here are pronounced differently, it is virtually impossible that theater audiences should hear in them a deliberate pun by Dr. Dysart on the boy's name. Yet I would argue that Shaffer has pleased himself by punning privately and visually in the script, and that he has left the pun here to prod actors and directors into sharing the psychiatrist's wry sense of his own helpless fascination with the strangeness of Alan Strang, whose face in Dysart's dream peers into the therapist's face.

This reflection leads to a recognition that significant names in theatrical productions, except very obvious ones like Everyman or Malaprop, differ markedly from those in fiction, where readers are not distracted from words by the physical movement of actors speaking them - and where many printed (visual) repetitions can eventually impress themselves upon even hasty or insensitive readers. With a theatrical script, on the other hand, the visual impact of names has its chief and perhaps only reliable effect on the actors who read them repeatedly before speaking them in rehearsal and performance; and the playwright may therefore expect that his fellow professionals will see more in the names than casual hearers and amateurs will - just as a painter, carefully observing such techniques as brushstrokes, will see more in a painting than nonpainters will. All unaware, then, theater patrons may be affected at second hand by significant nomenclature.

Repression and hypocrisy have seldom received a more stunning rebuke than Peter Shaffer delivered in Equus, and his skill in marshaling significant names has an important but as yet 
unrecognized share in the impact of that rebuke. These varied terms, with their many different associations, are all real names, yet in context they have symbolic overtones. Taken together, they constitute a pattern of verbal symbolism, analogous to the astonishing visual symbolism practiced by some Dutch and Flemish painters of the seventeenth century, who were once thought to be mere "genre" painters of domestic scenes. ${ }^{9}$ Like their visual symbols, Shaffer's verbal symbols extend and deepen the surface meaning of the work containing them, enriching and embellishing it in ways that are not immediately apparent; and those meanings set up reverberations in the minds of readers, actors, and theatergoers alike - but most of all in the actors who bear and speak those names. ${ }^{10}$

\section{Hampden-Sydney College}

\section{Notes}

1. Hanks and Hodges (Surnames 159) point out that "any of various places" named Dysart, not only the one near Fife, might give the surname Dysart to persons who lived there. Joseph Burner Clower, Jr., informs me that his native Shenandoah County in Virginia has many residents named Dysart; the telephone book lists more than a score.

2. For this and other suggestions I am indebted to William Collar Holbrook.

3. Alan's parents, Frank and Dora, also bear the surname Strang, but with them it suggests the psychological halters of religious fanaticism and of atheism. She is a rigid, pious, Bible-quoting enthusiast, aptly called Dora, a name which indicates her adoration of God. He, on the other hand, is a declared atheist, whose first name, Frank, is an ironic reversal of the secrecy with which he pursues sensual pleasure through pornographic films.

4. For other accounts, see Anderson 40-41 and Quaife 164, 167-72, 179.

5. Jill Mason, the girl who helps Alan get his job at the stables and who tries to initiate him into the mysteries of sex, is given a pair of names that do not resonate quite so broadly as the others. Jill recalls the nursery rhyme of Jack and Jill, wherein Jack falls down and breaks his crown; so Shaffer may 


\section{Names 41.3 (September 1993)}

have intended her first name to echo Alan Strang's mental disturbance. Since the boy rejects her at the crucial moment, Jill can be said to be jilted, too. Her surname Mason may allude to secret religious rites like Alan's worship of horses, but Jill is never a participant in those rites; more probably her surname carries its original sense of a constructive craft, as a reinforcement to her function of offering a sane and healthy alternative to Alan's obsession with horses.

6. For this point and others I am indebted to Stephen Cady Coy.

7. For this and other identifications I am indebted to Graves Haydon Thompson.

8. It is tempting to see a source for Jill's bare torso and a confirmation of Hesther Salomon's first name in another, much later painting, Esther Adorning Herself (1841), by Théodore Chassériau, in which a topless young woman, arms upraised to her hair, looks frankly into the viewer's eyes. This picture is in the Louvre.

9. For example, Jan Miense Molenaer's painting of a musical party had been called simply "A Musical Party" until Art Historian P. J. J. Van Thiel showed (in a 1967 essay, "Marriage Symbolism in 'A Musical Party' in the art journal Simiolus) that it is full of astonishing visual symbols which together make it an allegory of marital virtues: fidelity, temperance, harmony, and so on. Since Van Thiel's study, and because of it, the painting has become known as "An Allegory of Marital Fidelity" (Connor, $J 1$ ).

10. For general suggestions and for his article listed below, I am indebted to Michel Grimaud, who heard a draft of this essay at the annual meeting of the American Name Society in New York in 1992.

\section{Works Cited}

Anderson, Nels. Desert Saints: The Mormon Frontier. Chicago: U Chicago P, 1966. (Originally published in 1942).

Black, George F. The Surnames of Scotland: Their Origin, Meaning, and History. New York: Public Library, 1962.

Chadwick, Nora K. Celtic Britain. New York: Praeger, 1964.

Connor, Sibella. "Portrait of a Marriage," Richmond TimesDispatch (11 Oct. 1992), J 1, 10. 
Grimaud, Michel. "Onomastics and the Study of Literature." Comparative and General Literature 38 (1989):16-35.

Hanks, Patrick, and Flavia Hodges. A Dictionary of First Names. New York: Oxford UP, 1990.

. A Dictionary of Surnames. New York: Oxford UP, 1988.

Levey, Michael. A Room-to-Room Guide to the National Gallery, 3d ed. rev. London: National Gallery, 1969.

Quaife, Milo M. The Kingdom of Saint James [J. J. Strang]: A Narrative of the Mormons. New Haven: Yale UP, 1930.

Shaffer, Peter. Equus. New York: Avon, 1975.

Smith, Warren S. "Peter Shaffer." Dictionary of Literary Biography, vol. 13: British Dramatists Since World War II (1982), 451-469.

"Strang, James Jesse." Columbia Encyclopedia, 1963 ed.

"Strang, James Jesse." Encyclopedia Britannica, 1975 ed. 